\title{
Mistä on yrittäjät tehty?
}

\author{
Roope Uusitalo
}

$Y_{\mathrm{jen}}^{\mathrm{n}}$ rittäjät ovat kummallista porukkaa. Tilastojen valossa tarina yrittäjästä, jolla ei ole koskaan lomaa ei näytä kovin väärältä. Työvoimatutkimuksen mukaan yrittäjät tekevät keskimäärin kymmenen tuntia pitempää työviikkoa kuin palkansaajat. Saman tilaston mukaan yrittäjillä on vuodessa vajaat 60 työpäivää enemmän kuin palkansaajilla. Se on kaksi kertaa valtion virkamiehen vuosiloman verran. Yrittäjät puurtavat siis työssä suurinpiirtein koko palkansaajien kesälomat ja lauantait päälle.

Tästä uurastuksesta yrittäjät tienaavat kovin vähän. Uusimman Tulonjakotilaston ${ }^{1}$ mukaan yrittäjien vuositulot olivat vuonna 1998 keskimäärin 107500 markkaa, kun palkansaajat ansaitsivat 30000 markkaa enemmän. Tilastojen mukaan yrittäjien tulot myös vaihtelevat palkansaajien tuloja enemmän. Yrittäjyys on riskibisnestä.

Mikä muu kuin sula hulluus siis saa yrittäjät vaihtamaan säännölliset palkkatulot, vapaat lauantait ja aurinkoiset heinäkuut epävarmaan yrittäjäelämään? Tässä on yrittäjyystutkimukselle askarreltavaa. Keskustelun tason nostamisen voisi aloittaa erottelemalla yrittäjyyskeskustelusta faktat ja fiktion.

Esimerkiksi Valtionvarainministeriö on huolestunut Suomessa vallitsevasta yrittäjyysvajeesta. VM pelkää, että palkkatyö on toimeentulon varmuuden ja sosiaaliturvan huomioon ottaen liian houkutteleva vaihtoehto yrittäjäuraan verrattuna. Yrityksen perustaminen on turhan monimutkaista ja verotuskin saattaa haitata yrityksen kehittämistä.

Nämä pelot näyttävät kuitenkin olevan sopiva sekoitus faktaa ja fiktiota. Tilastojen valossa on faktaa se, että palkkatyö näyttää yrittäjyyteen verrattuna ylivoimaisen houkuttelevalta. Yrittäjyysvaje sen sijaan näyttäisi kuuluvan fiktio-osastolle.

Vuonna 1999 Suomessa oli Työvoimatutkimuksen mukaan 320000 yrittäjää. Näistä va- jaa kolmannes oli maanviljelijöitä, joita kaikki tilastonikkarit eivät pidä ollenkaan oikeina yrittäjinä. Maatalous poislaskien yrittäjiä oli aika tarkkaan kymmenen prosenttia työllisistä. OECD:n mukaan $^{2}$ vastaava luku oli Ruotsissa 9\%, Norjassa $5 \%$, Saksassa $9 \%$ ja yrittäjyyden ihmemaassa USA:ssa 7 prosenttia. Lukujen vertailukelpoisuus saattaa olla tilastointitavasta riippuen kyseenalainen, mutta ainakaan kovin suuresta yrittäjyysvajeesta luvut eivät kerro. Sen sijaan yrittäjyysvaje näyttää paljon pahemmalta, jos Suomen tilannetta verrataan vaikka Italiaan, Espanjaan tai Turkkiin, joissa yrittäjien osuus työllisistä pyörii 20 prosentin paikkeilla. Turkkilaisten työmarkkinoiden joustavuudessa suomalaisilla tosin on muutenkin paljon kirittävää.

Kun yrittäjät ovat kuitenkin markkinatalouden vetureita ja tuiki tärkeiden uusien työpaikkojen luojia, niin voidaan toki keskustella siitä, miten yrittäjyyttä voitaisiin edistää. Nyt tullaan suhteellisten vaikeiden kysymysten pariin, joista tutkimuksella on usein vähänlaisesti sanottavaa. Yrittäjyystutkimus on pyrkinyt selvittämään esimerkiksi luotonsaannin helppouden ja yrittäjä- ja palkkatulojen suhteen vaikutuksia yrittäjäksi ryhtymiseen. Näissä tutkimuksissa perusongelmana tahtoo olla syiden ja seurausten erottaminen. On vaikea sanoa, miten yrittäjä olisi pärjännyt palkkatyössä tai palkkatyöläinen yrittäjänä. Samaten on vaikea löytää potentiaalisten yrittäjien välisiä eroja, joiden perusteella voisi sanoa jotain luottorajoitteiden vaikutuksesta yrittäjäksi ryhtymiseen.

Ehkä luotettavimmat tulokset liittyvätkin joidenkin taustatekijöiden vaikutukseen. Yrittäjyys näyttää esimerkiksi periytyvän voimakkaasti. Suomessa yrittäjäisien pojista oli kolmekymppisinä yrittäjiä 25 prosenttia, kun yrittäjien osuus kaikista samanikäisistä oli 9 prosenttia $^{3}$. Samantapaisia tuloksia on saatu myös amerikkalaisista tutkimuksista $^{4}$.

Yrittäjyyden edistäminen vanhempien yrit- 
täjätaustaa muuttamalla on hiukan hidasta politiikkaa. Olisi hyödyllisempää löytää yrittäjyyttä edistäviä tekijöitä, jotka vaikuttavat alle kolmenkymmenen vuoden viiveellä. Mutta mitä nämä voisivat olla? Mielenkiintoisia vastauksia kysymykseen saadaan tarkastelemalla armeijan psykologisten testien vaikutuksia yrittäjäksi ryhtymiseen. Armeija testaa kaikki asevelvolliset kaksiosaisella testillä, josta ensimmäinen mittaa lahjakkuutta ja toinen erilaisia upseerintehtävissä tarvittavia ominaisuuksia. Kun verrataan vuoden 1982 asevelvollisten testituloksia ja näiden miesten ammattiasemaa kaksitoista vuotta myöhemmin vuonna 1994, havaitaan, että yrittäjät eivät ole sen lahjattomampia tai lahjakkaampia kuin muutkaan ikäisensä miehet. Sen sijaan miehet, jotka saavat korkeita pistemääriä johtamismotivaatiota ja energisyyttä mittaavassa testiosiossa, ovat muita useammin yrittäiiä. Samaten miehet, jotka ovat testin mukaan "varovaisia" ja "harkitsevia", uskaltautuvat yrittäjiksi muita harvem$\min ^{5}$. Yrittäjistä siis löytyy yhteisiä piirteitä: roh- keutta ja riskinottokykyä.

Yrittäjäkasvatuksen haasteena voisikin olla, miten istuttaa yrittäjäominaisuuksia potentiaalisiin yrittäjänalkuihin. Tämä on helpommin sanottu kuin tehty. Suomalaisesta koulutusjärjestelmästä ei ainakaan näytä yrittäjähengen luomisessa olevan apua. Varsinkin korkeakoulut kouluttavat edelleen virkamiehiä julkisen hallinnon virkoihin. Vähintään alemman korkeakoulututkinnon suorittaneista työskenteli julkisella sektorilla vuonna 1999 yli puolet, kaksinkertainen osuus kaikkiin työllisiin verrattuna ${ }^{6}$. Yrittäjiä oli esimerkiksi ylemmän korkeakoulututkinnon suorittaneista vain kahdeksan prosenttia, kun kaikista työllisistä yrittäjiksi laskettiin 14 prosenttia.

\section{Viitteet}

1 http://www.stat.fi/tk/el/tulo/sislu98.html

2 OECD Employment Outlook 2000

3 Uusitalo, R. (1999), "Homo entreprenaurus", Valtion taloudellinen tutkimuskeskus, keskutelualoitteita 205.

4 Dunn, T. ja Holz-Eakin, D. (1996), "Financial capital, human capital, and the transition to self-employment: Evidence from intergenerational links", National Bureau of Economic Research, Working papers 5622.

5 Uusitalo, R. (1999).

6 Työvoiman koulutus ja ammatit, Tilastokeskus, Työmarkkinat 2001:2.

\section{YRITTÄJÄTIETOA PÄHKINÄNKUORESSA}

Suomen Yrittäjien jäsenkunnan

\section{koulutusjakauma:}

$$
\begin{aligned}
& \text { kansakoulu } 20,5 \% \\
& \text { peruskoulu } 6,9 \% \\
& \text { ammattikoulu } 28,4 \% \\
& \text { opistotasoinen tutkinto } 30,7 \% \\
& \text { ylioppilas 2,7\% } \\
& \text { yliopisto tai korkeakoulu } 10,8 \%
\end{aligned}
$$

Yritysten määrä laski lamavuosina voimakkaasti, mutta lähti jälleen 1995 nousuun. Vuonna 1999 Suomessa oli noin 220000 yritystä poislukien maatalousyrittäjät. Niistä oli mikroyrityksiä (1-9 henkeä) 93 prosenttia, pienyrityksiä (10-49 henkeä) kuusi prosenttia, keskisuuria yrityksiä (50-249 henkeä) yksi prosentti sekä suuryrityksiä (yli 250 henkeä) 0,2 prosenttia.

Liki 70 prosenttia yrittäjistä on 40-60-vuotiaita. Alle 30-vuotiaita on vain 4 prosenttia. Toimialoittain koko maan jakauma oli seuraava: palvelut $37 \%$, kauppa 23, teollisuus 12 , rakentaminen 13 , liikenne 11 ja muut viisi prosenttia. 